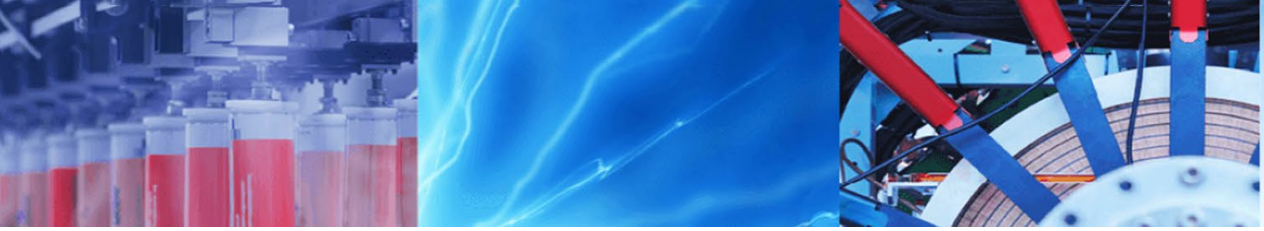

Research Article

\title{
Textile natural fibers production regarding the agroforestry approach
}

\author{
Larissa Oliveira Duarte $^{1}$ ([) $\cdot$ Lais Kohan $^{1}$ (i) $\cdot$ Luciano Pinheiro $^{1}$ (D) $\cdot$ Homero Fonseca Filho $^{1}$ (D) $\cdot$ Julia Baruque-Ramos $^{1}$ (D)
}

(c) Springer Nature Switzerland AG 2019

\begin{abstract}
As sustainability is becoming an important topic for both agriculture and the textile sector, there is an increasing market demand for plant-based fibers production. Diversified farming systems, such as agroforestry, have received considerable attention for their potential to contribute to more environmentally sustainable and socially just agricultural methods, that offers a smart use of water and soil nutrition. They can be a direction for rural development through contributions in agrobiodiversity, livelihood diversity, labor availability and economic growth. They are currently being promoted in many regions to contribute for food security, climate change adaptation and mitigation. In this study, the research methodology was based on a systematic literature review and secondary data collection and analyses. The aim was to investigate initiatives towards sustainable textile fibers cropping, including different species and plantation methods. The results indicate few cases worldwide and suggest cotton as the main experimented specie, generally cultivated with two other ones. They were identify three methods applied in cotton crops: (1) crop rotation, (2) agroecological intercropping and (3) agroforestry. Results also demonstrates different production challenges, concerning machinery development to mixture crops, ideal species groups, economic viability and process scalability. Forest management methods that can sustain good mixes of tree species need to be designed, promoting rich agrobiodiversity landscapes. Thus, defining, measuring and rewarding good farming practices are the main possible drivers to motivate farmers to change to new approaches towards sustainability in textile fiber production. Further investigation is demanded to evaluate different species possibilities and cropping maintenance, as well as addressing public policies and coordinating stakeholders interests.
\end{abstract}

Keywords Natural fibers $\cdot$ Textiles $\cdot$ Agrobiodiversity $\cdot$ Agroforestry $\cdot$ Sustainability

\section{Introduction}

The interest in plant fibers for textiles manufacturing has increased in recent years, due to market demands on sustainable processes [1-3]. Both agricultural and textile industries has experienced social environmental issues linked to unhealth workers conditions, water and soil pollution and biodiversity loss, characterized by the intense use of chemical products and natural resources [4]. Researchers and practitioners are devoting attention to environmental sustainability, as they face the challenge of achieving a balance between environmental and business needs [5]. In this way, global apparel brands have developed their own eco-matrices for product development [3].

According with Romeiro [6] sustainable agriculture has three long-term goals: (1) quality of life (to satisfy personal, family, and community needs for health, safety and food); (2) environmental quality (to enhance soil nutrition, water, air, and other resources); (3) economics (to be profitable). Therefore, intercropping and agroforestry are mixed plant species cultivation systems that can potentially reduce pressure on land and water resources by increasing its efficiencies, through exploitation of complementarities between species that may generate higher yields $[7,8]$. Agroforestry integrates trees into the agricultural

$\triangle$ Larissa Oliveira Duarte, larissaoliveiraduarte@hotmail.com | ${ }^{1}$ School of Arts, Sciences and Humanities, University of Sao Paulo, Av. Arlindo Bettio, 1000, São Paulo, SP 03828-000, Brazil.

SN Applied Sciences (2019) 1:914 | https://doi.org/10.1007/s42452-019-0937-y

Received: 7 June 2019 / Accepted: 16 July 2019 / Published online: 24 July 2019 
landscape, providing not only food, fiber, fodder, wood, fuel, but also accumulating biomass [9].

Studies in several disciplines have shown an increasing interest in these diversified organic cropping systems, because of their regenerative potential, nutrient retention, pest and weed control, carbon sequestration and counteract resource degradation and desertification $[8,10,11]$. In the case of sustainable fibers cultivation, a coexistence crop configuration seems a promising avenue to maintain a wide range of cultivated biodiversity [12], while at the same time improving income and living conditions for local populations [13]. This provides a unique opportunity and imperative to rethink the design and implementation of agricultural systems that not only maximize productivity, but also ecosystem and socioeconomic benefits [14]. However, finding the optimal strategy depends not only on the agronomic parameters, but also on the socio-economic and agro-ecological drivers of change from one production system to another [15].

The United Nations Sustainable Development Goals, are the blueprint to achieve a better and more sustainable society. Addressing global challenges, including those related to poverty, inequality, climate, environmental degradation, prosperity and justice. The goals are interconnected and they are target by 2030 [16]. To meet them, innovative approaches are necessary that actively attempt to meet multiple goals simultaneously [17]. This research is directly related with the goal 12 (Ensure sustainable consumption and production patterns), and goal 15 (Protect, restore and promote sustainable use of terrestrial ecosystems, sustainably manage forests, combat desertification, and halt and reverse land degradation and halt biodiversity loss).

Agricultural systems are transitioning away from the dominant industrial agriculture paradigm designed for production, self-sufficiency, efficiency and affordability [18] to one of sustainable agriculture that conserves land, water, and plant and animal genetic resources, and is environmentally non-degrading, technically appropriate, economically viable and socially acceptable [19].

Therefore, the purpose of this research is to investigate and identify initiatives on agroforestry for textile fibers cultivation, describing species and plantation methods worldwide. The importance is related to the influence of these new researches and markets addressing plant diversity, sustainable agriculture and fibers production.

\section{Research methods}

The methodology of this study consisted in two phases. The first, defined through a systematic literature review, combining the topics of "agroforestry", "plant fibers", "cultivation", "textiles" and "sustainable fashion", search at Web of Science platform. After that, articles were selected considering the relevance of the contents. The second, was consisted in date base search in reports and documents analyses, within different organizations and institutions, such as Textile Exchange, to map examples of more sustainable cultivation methods, aiming the production of natural fibers for textile manufacturing. It is worth of mentioning that Textile Exchange is a global non-profit organization (textileexchange.org), working to drive industry transformation in preferred fibers, integrity and standards, identifying best practices in relation to agriculture, materials, processing, traceability and product lifecycle in order to reduce the impact of industry in water, soil and air, and in the human population [20].

\section{Results and discussion}

\subsection{Sustainability and the textile sector}

Sustainability has become one of the key factors for long-term business success [21] and one of the strategic focal points of organizations [22]. A sustainable business model aims at improving the economic, environmental, and social effectiveness integrated [23], requiring a holistic approach to resource consideration and addressing the needs of partners and customers [24]. To achieve sustainable development, organizations can innovate their products, processes and services [25]. These innovations are decreasingly accomplished solely due to their internal research and development activities, but they are increasingly looking outside their boundaries to other actors with whom they can collaborate [26].

The textile industry is one of the world's largest industrial sectors in terms of volume, with rapidly growing global demand driven by increases in population and average income [27]. In the textile and apparel industry, environmental impacts start at the initial stage of production itself and can be grouped under categories such as raw material production, where chemicals toxic in nature is used in growing cotton [1]. Next is the stage of textile manufacturing, dyeing and finishing where chemicals and solid wastes arising from yarn manufacturing of natural fibers are released in water $[28,29]$. Therefore, common environmental practices for achieving sustainability can include organic-fiber usage, material recycling or reuse, technology implementation (including clean technology and information technology), product certificates, green processes and product design, green manufacturing and logistics, and product traceability [5].

The sustainable raw materials driver contemplates the development and adoption of different types of 
environmentally-friendly raw materials such as organic cotton, hemp, flax, jute, bamboo and recycled fibers [30]. Fair-trade labeling, code of conduct initiatives, internal and social auditing, and looking beyond first-tier suppliers are attempts to improve sustainability within the social dimension [31]. Corporate social responsibility programs are implemented in firms to improve the living standard of workers and their families as well as contribute to local communities and the economy [32]. The focus has shifted from sustainability of internal processes and products the brand sells to sustainability of all the process, inside the company and in the whole supply chain that creates the product [31]. And education to ensure consumers are fully cognizant of the impacts of their purchasing and consumption decisions [33].

One such strand of work coming out of sustainable fashion is focused on alternative business models, built around the purchasing and selling of fewer higher value and higher quality clothes. With her concept of 'Slow Fashion', the designer and academic Fletcher [34] argues that to be sustainable, fashion requires a wholesale shift in our relationship with clothing. The connection to 'better rather than more' ideas from industrial ecology is through the belief that value and quality can be increased by paying workers fair wages, generally improving working conditions and emphasizing the use of renewable materials by designers, aiming to drive a road map for sustainability, based in the development of processes, products and services more responsible [35]. Thus, with the demand for more ecofriendly, biodegradable and renewable materials, the interest in vegetable fibers has increased [31].

\subsubsection{Textile natural fibers}

Textile fiber means any substance, natural or chemical, having a length much greater than its thickness and having suitable characteristics for spinning and weaving. Six thousand years ago, linen was already used in Egypt. China was the cradle of silk and in ancient India, techniques associated with the use of cotton have been developed. Sisal was already used in textiles by pre-Columbian civilizations, together with animal fiber such as vicuna and llamas in the making of clothes [36]. Until the end of the nineteenth century, fibers used as raw material for making fabrics were exclusively those found in nature [37]. The first chemical fibers were produced in 1885. The pulp extracted from wood and transformed chemically originated the rayon, designed to be an "artificial silk". Since then, numerous fibers have been developed in laboratories with the purpose of satisfying the needs of the industries of different productive sectors and, consequently, widely employed in the manufacture of new fabrics [36].

Fibers can be defined as objects that have high aspect ratio (length/diameter) [37]. They can be classified into natural and man-made fibers (Fig. 1) [38].

Natural fibers are obtained from natural sources, being of two types: protein fibers, which are obtained from animal resources, such as silk, wool and hair, and cellulosic fibers, which are obtained from plants, such as flax, jute, date palm and cotton [40]. Cellulosic fibers can be classified based on the part of the plant from which they are extracted. For instance, fibers extracted from the stem are classified as bast fibers, whereas fibers extracted from the leaves are classified as leaf fibers. In addition to other parts of the plants, such as, seed, fruit, stalk, or grass [39].

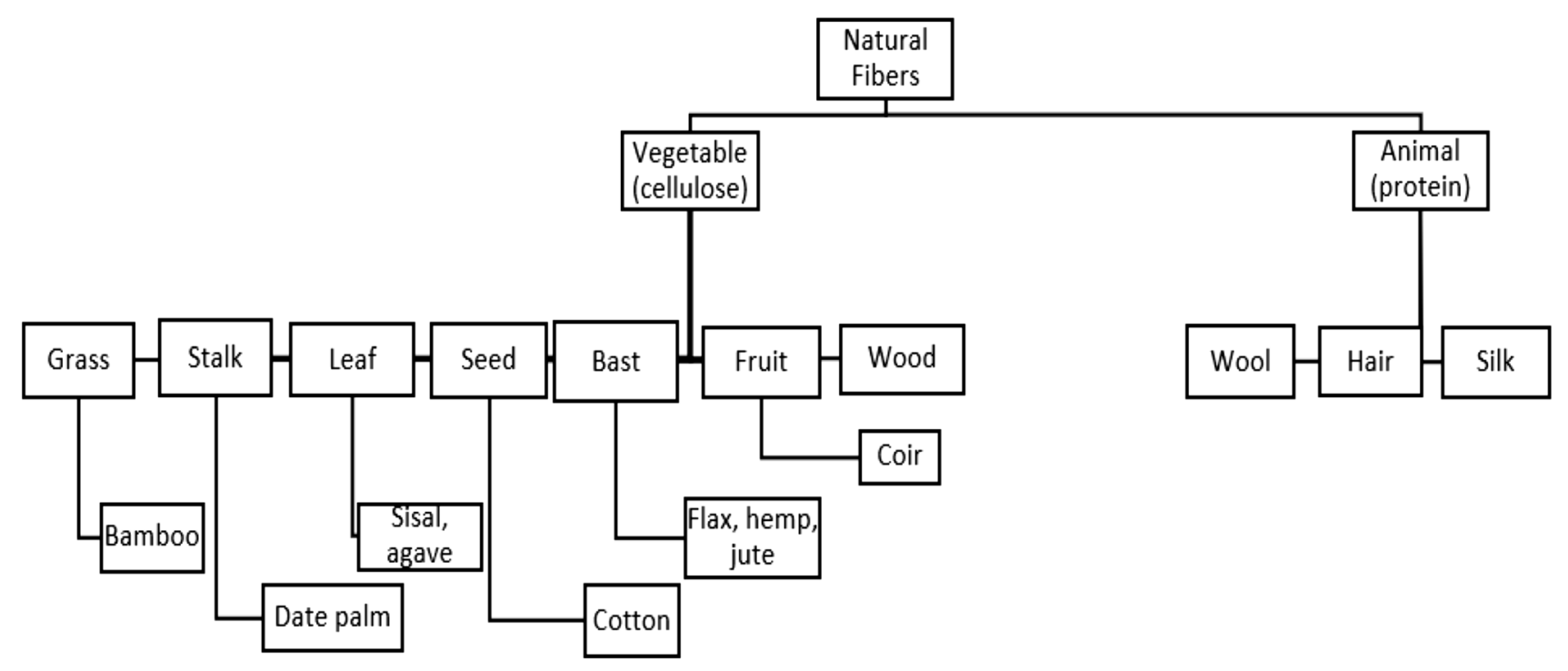

Fig. 1 Classification of textile natural fibers. (Adapted from [39]) 
The most widely known uses of fibrous plants, apart from textiles, are pulp and paper industry, cosmetic, composite, biocomposite production, food products (seed and oil), production of insulating and lawn mats, and finally of renewable energy. The increasing demand for more sustainable and renewable materials, has raised the interest in natural fibers [37]. Vegetable fibers are not only environmentally-friendly, but they also have high specific properties, due to their light weight (specific gravity generally near 1.0-1.5). Their main chemical component is cellulose, which is a natural polymer based on glucose, such as cotton fiber. For their construction, bundles of cellulose molecules aggregate in the form of microfibrils, and these construct fibrils constituting the cellulosic fibers. Other chemical components are lignin and hemicellulose, which as cellulose, are polar substances. There are also small percentages of pectin, water-soluble substances and waxes $[36,41]$.

\subsection{Sustainability and agriculture}

One of the most discussed topics in today's world is sustainable agriculture, and its biggest obstacle is the use of chemicals. In this way, the most important issue when it comes to sustainable agriculture is undoubtedly organic farming. It can generate economic benefits, such as reduction of inputs and water resources, as well as reducing pest risk, increasing productivity, soil quality and ecosystem diversity. Traditional diverse agricultural landscapes have been replaced by monocultures of specialized varieties that have high yields and high known commercial potential, but which demand a higher input of pesticides, herbicides and fertilizers [15]. The agroecological performance of the agroecosystems, in terms of disease management and landscape preservation, is an important motivation for adopting agrobiodiversity rich production practices, without the use of agrochemicals.

Agriculture affects everything from greenhouse gas emissions to biological diversity, water quality, soil erosion, pollination services, carbon sequestration, human health, livelihoods and food security. The long-term success of sustainable systems depends on not only science and practice, but also on developing the community, business, and policy supports that can ensure economic sustainability [42]. Priorities of the rural development include, favor the knowledge and innovation transfer in agriculture, forestry and the rural areas. Therefore to improve the viability and competitiveness of all the types of agriculture in all regions and promote technological innovation and the sustainable management of the forests. Promote social inclusion and poverty reduction in the rural areas [43].

Sustainable intensification in this context considers the biophysical, social, cultural, and economic background, with selection of the optimal mix of approaches for agricultural production. Integrated systems can combine crop production, livestock, and forestry, supporting the production of at least three types of product from the same land area over a defined period These systems, based on intercropping, succession, and/or rotation, can optimize the biological cycling of nutrients between plants and animals, improving production efficiency and maintaining long-term soil fertility, considering they are also organic methods. For example, an integrated system includes tropical forage plants, which replenish soil organic matter, recycle nutrients underground, and contribute to biological plowing and microbial activity due to their extensive root systems [44].

The term 'sustainable agriculture' means: an integrated system of plant and animal production practices having a site-specific application that will, over the long term [6]:

- Satisfy human food and fiber needs;

- Enhance environmental quality and the natural resource base upon;

- Make the most efficient use of non-renewable resources and on-farm;

- Resources and integrate, where appropriate, natural biological cycles;

- Sustain the economic viability of farm operations;

- Enhance the quality of life for farmers and society as a whole.

For most developing countries, the need to change the technological standard of agricultural modernization for ecological reasons is compounded by the need for change for socio-economic reasons [6]. In the context of designing more sustainable agricultural systems, and in view of paradigms such as circular economy, agroecology and smart or digital farming [19], there is a need to consider how existing co-design and co-innovation approaches in agriculture can be further opened. This includes a need to better understand, develop and validate novel design methods, tools and techniques capable of supporting both democratic and radical innovation, including concepts, behaviors and technologies among dispersed and autonomous entrepreneurs (farmers), as well as with other actors with diverging interests and complex power relationships $[12,45]$.

\subsubsection{Organic cropping}

Organic agriculture uses only organic fertilizers and pesticides to ensure the sustainability of agroecological systems. However, the low yield combined with the high cost of labor, makes organic agriculture financially unattractive for the farmers, who make labor and capital investments 
in anticipation of good financial return. Therefore, it is challenging to make organic agriculture financially better than conventional agriculture, unless appropriate policy interventions enabling organic products to fetch premium price are made [46].

Expansion of conventional cotton farming, for instance, is considered as one of the most polluting forms of agriculture, driving major land use change and loss of biodiversity. It requires intensive use of inputs, synthetic chemical pesticides, fertilizers, growth regulators, hormones, defoliant and irrigation $[46,47]$. Just as the world faces crises over water, climate change, energy and biodiversity [4], the excessive use and misuses of agrochemicals can significantly affect the natural biological system, pollute soil and water resources [48-50]. Have an adverse impact on agricultural workers health and living conditions [1-3]. Furthermore, the inefficient cotton production management practices can result in inefficient use of limited land and higher production costs.

On other hand, organic cotton offers environmental benefits because its production is based on farming practices that support ecological balance, which includes avoiding the use of synthetic pesticides or fertilizers, maintaining water and soil quality, and conserving wildlife. Furthermore, it protects soil quality, biodiversity and water supply, avoiding water pollution, safer for farmers and for the health of their communities [51].

Organic farming is often promoted as a means of addressing the economic, environmental and health risks of conventional cotton production, and it is slowly gaining ground in the global cotton market [50]. Organic and fair-trade cotton, are widely seen as opportunities for smallholder farmers to improve their livelihoods thanks to higher returns, lower input costs and fewer risks [51]. The majority of organic farmers perceives improved soil quality, improved health conditions, and positively assess their initial decision to convert to organic farming [52]. Organic farming has also been shown to make land easier to plough and retain water, helping crops to sustain periods of drought better [1]. Despite that, the major disadvantage of organic farming is the high manual labor input required [52].

\subsubsection{Agroforestry approach}

Key ecosystems that provide numerous services essential to food and agriculture, including fresh water supply, risk protection and habitat provision for species such as fish and pollinators, are rapidly declining. Restoration of the ecosystem is defined as a process of reversing the degradation of ecosystems, such as landscapes, lakes and oceans, to restore their ecological functionality; in other words, to improve the productivity and capacity of ecosystems to meet the needs of society [9]. This can be done by allowing the natural regeneration of overexploited ecosystems, for example, or by planting trees and other plants [7]. Currently, about $20 \%$ of the planet's surface is declining in productivity, with fertility losses linked to erosion, depletion and pollution in all parts of the world. By 2050, degradation and climate change could reduce crop yields by $10 \%$ globally and by as much as $50 \%$ in certain regions. One important goal of an agroforestry system is to restore a degraded with biodiversity and integrated mix of species, covering the soil, improving water retention and soil quality [53].

Regenerative agriculture can be directly related to the sustainability in cropping production. Regenerative farming systems can provide organic crops, greater ecosystem services and profitability for farmers than an input intensive model production [54]. In this turn, agroforestry aims to meet regenerative goals. Agroforestry is defined as a land-use that involves deliberate retention, introduction or mixture of trees or other woody perennials in crop/annual production fields to benefit from the ecologic and economic interactions [55-57]. A basic agroforestry configuration is simply the integration of suitable woody perennials into an agricultural landscape. Agroforestry practices also have the potential to repair degraded and deforested land and restore or enhance the multifunctionality of landscapes [58]. By our definition a regenerative agroforestry system should be highly integrated, densely planted, multistoried, and contain multiple species (Fig. 2) [14].

Soils are crucial to managing climate change. They contain two to three times more carbon than the atmosphere. Plants circulate carbon dioxide from the air to soils, and consume about one-third of the $\mathrm{CO}_{2}$ that humans produce. Of that, about 10-15\% ends up in the Earth. Yet one-third of the world's soils are degraded. Poor farming practices, industry and urbanization take their toll [58]. The goal of regenerative farming systems is to increase soil quality and biodiversity in farmland while producing nourishing farm products profitably [59]. For the purpose

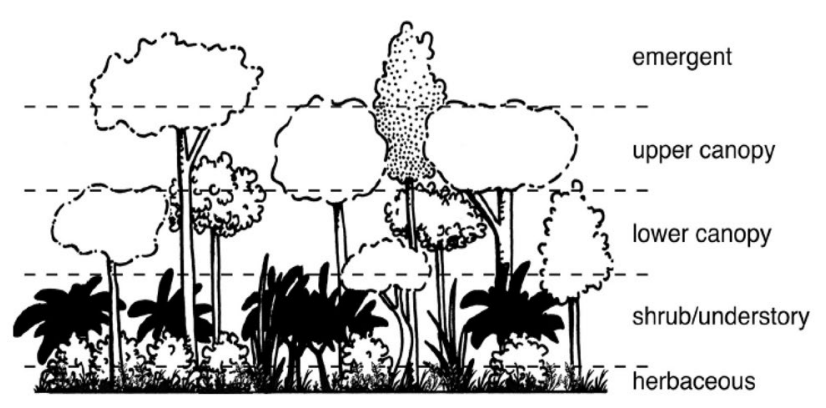

Fig. 2 Agroforest structure and descriptive terms used to indicate species layers [14] 
of proposed agroforestry standards, the broad regenerative agriculture goals are summarized as follows [14]:

- Soil: Contribute to building soils along with soil fertility and health.

- Water: Increase water percolation, water retention, and clean and safe water runoff.

- Biodiversity: Enhance and conserve biodiversity.

- Ecosystem health: Capacity for self-renewal and resiliency.

- Carbon: Sequester carbon.

Ecological actants are present across agriculture-related sectors and could also act as a unifying feature to link the various complex systems governing natural resource management sectors [60]. Thus, one key implication of the expanded range of actors is that there is a need to better consider the ecological dimension as a steering factor for innovation niche design [19]. For sustainable agricultural innovation the broadest range of actors and actants needs to be considered, since the interactions between multiple actors and actants can shape the ability of other actors to innovate [61, 62]. Embracing regenerative development, by adopting measures that implicitly drive the regeneration of soils, forests, watercourses and the atmosphere, in contrast to the vexed policy of 'sustainable development' which essentially permits these vital elements to be maintained in conditions of inexorable degradation, as has been the case for a number of decades [60].

\subsection{Sustainable cultivation methods of textile vegetable fibers}

Natural plant fibers such as cotton, flax, hemp, jute, sisal, banana, coir and bamboo, offering several benefits with respect to synthetic fibers, such as abundance and low cost, renewability, ecofriendly and biodegradability. They were identify three main methods, applied in cotton cropping: (1) crop rotation, (2) agroecological intercropping and (3) agroforestry.

Sustainable methods of fibers cultivation, first found cotton crop rotations as well-accepted approach to manage pests and diseases and reduce the demand for herbicides. It consists in different types of crops in the same area in sequenced seasons [63]. The requirements for the cultivation of cotton plants are long frost-free periods, more sunlight, moderate rainfall and fairly heavy soils containing a moderate level of nutrients. Considering each specie will demand a different approach for soil and irrigation characteristics [64]. Diverse crops also provide nourishment to the biological community below ground (Fig. 3).

Examples of organic cotton in agroecological intercropping were found in Brazil, intercropped with food crops such as corn (Zea mays), green beans (Vigna unguiculata), sesame (Sesamum indicum) and beans (Cajanus cajan) and cultivated in family farms and using manual harvesting $[65,66]$. The objective is increasing the productive alternatives and the economic flexibility of family systems [67]. Different type of integrated species and a cover soil, might contribute to a better productivity, as it tends to be more stable in intercrops than in sole crop yields, due to differences in species responses to adverse weather conditions or to pest and disease outbreaks [68]. Increasing plant diversity at farm and landscape scales, together with use of agroecological practices, can also reduce farmers' vulnerability to social and environmental variabilities by reducing the need for non-renewable inputs [11].

According with Araujo et al. [69] in Brazil, stallholder farming had also experimented cotton plantation (BRS 186 and BRS 201) with peanut (L7 and BR-1). Their research demonstrated ideal plantation seasoning and compared economic value generated. The area was better utilized when the peanut was sown at the same time as the cotton. However, considering the economic indicators, no advantage demonstrated in cotton planted with the peanut, comparing with isolated crops, once the income generated with intercropping was less profitable. The research did not evaluate the environmental benefits of intercropping cotton and peanut.

Wang et al. [70] studies in China, suggested the agroforestry plantation of cotton (Gossypium hirsutum) and jujube trees (Zizyphus jujube) may increase yield and revenue especially during the early years of tree plantations. Jujube is grown widely for their fruits, and cotton is gaining popularity as an understory crop in young jujube plantations [71]. Increasing plant density could be applied to compensate the negative effects of trees on crop in the agroforestry [72]. Decreasing inter-specific competition
Fig. 3 Example of cotton crop rotation and species cultivated with cotton [63]

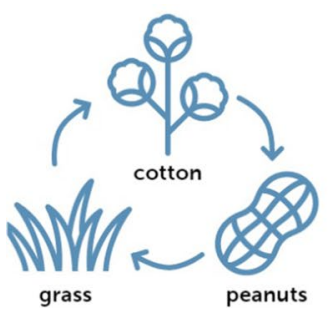

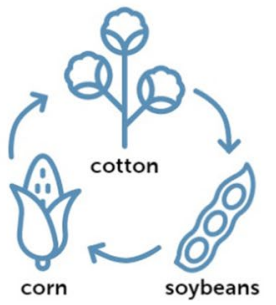

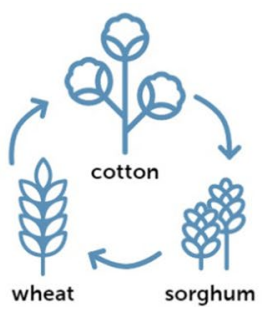


in jujube/cotton agroforestry by increasing the distance between the border cotton row and the tree line, significantly increased cotton yield due to an increasing in boll density and lint proportion [72].

Gnangle et al. [73] demonstrated its study for cotton and sorghum (Sorghum moench) production in an agroforestry of shea trees (Vitellaria paradoxa Gaertn) in Benin. It has shown that the productivity parameters for sorghum and cotton (plant height, yield and fresh biomass) are higher for plants grown outside the shea tree area than those under the coverage.

Wanvestraut et al. [74] in a study of competition for water in an alley cropping system consisting of pecan (Carya illinoensis) and cotton (Gossypium hirsutum) in a sandy loam soil in Jay, Florida, United States, found that sub-tropical and temperate zone alley cropping and annual or biannual root pruning of the tree species, may be advantageous to alleviate water stress of the associated agronomic species.

Thus, these findings are summarized in Table 1.

Although tree-crop mixtures may increase yield and revenue especially during the early years of tree plantations, limited knowledge is available on optimizing such systems by the choice of crop species with specific physiological traits [68]. Agroforestry seems to be widely used for food production; therefore, many studies in terms of fiber are needed, considering species adequate integration, distribution and management, economic viability, scalability, quality and volume of fiber production. They also demonstrates different production challenges, concerning machinery development to mixture crops, ideal species groups, economic viability and process scalability [68]. Textile Exchange [63] report on "Regenerative Agriculture in the Textile Supply Chain" indicated the main reasons demotivating farmers to change, such as: the effort and cost to change methods, education, timelines, commodity market price fluctuations, weather and aging population of farmers.

Defining, measuring and rewarding good farming practices are the main possible drivers to motivate farmers to change to new approaches towards sustainability in textile fiber production [63]. Despite significant evidence that green manures from agroforestry species can improve soil fertility, green biomasses from many agroforestry species have not been sufficiently explored. This possibility would be turning agriculture from a threat to an opportunity for conservation.

Interesting future studies might considerate different fibers species intercropping, such as flax, banana fiber, jute, wood-based textiles and many other, in order to offer more options to stakeholders needs.

Among the many environmental issues being addressed by public policies, the issue of sustainable ecosystem management is particularly challenging and pressing. Enhancing agroecosystem sustainability raises difficult challenges for environmental policy and requires both increasing knowledge on these complex systems to design effective solutions and coordinating stakeholders with diverging interests [12]. To reach a truly sustainable textile industry, it will probably be necessary to rely on a range of fibers from different feedstocks, produced on carefully chosen locations, suitable for different endproducts and produced below a certain maximum yearly sustainable yield $[75,76]$.

\section{Conclusions}

Sustainable cultivation methods can be developed for improving conditions on farming lands to favor increased biological diversity and soil nutrition, also providing diverse types of textile natural fibers. They were identify these three methods in cotton crops: (1) crop rotation, (2) agroecological intercropping and (3) agroforestry.

Focusing agroforestry potential for textile fibers cultivation, the results indicate few cases worldwide and suggest cotton as the main experimented species, generally cultivated in consortium with two other ones. They also demonstrate different production challenges, concerning machinery development to mixture crops, ideal species groups that do not compete, economic viability and process scalability.

Despite agroforestry seems to be widely used for food production, many studies in terms of fiber are still needed,

Table 1 Studies on cultivation of textile fibers in agroforestry systems

\begin{tabular}{|c|c|c|c|}
\hline Country & Species & Results & Authors \\
\hline China & Jujube/cotton & $\begin{array}{l}\text { Improves the local economy by harvesting additional cotton; may reduce wind } \\
\text { erosion and increase resource use efficiencies. }\end{array}$ & Zhang et al. [71], Wang et al. [70] \\
\hline Benin & $\begin{array}{l}\text { Sorghum/ } \\
\text { cotton/shea } \\
\text { tree }\end{array}$ & Productivity parameters are higher for plants grown outside the shea tree area. & Gnanglè et al. [73] \\
\hline US & Pecan/cotton & $\begin{array}{l}\text { Presented water stress and competition, suggesting annual or biannual root } \\
\text { pruning of the tree species may be advantageous. }\end{array}$ & Wanvestraut et al. [74] \\
\hline
\end{tabular}


considering species adequate integration, distribution and management, quality and volume of fiber production. New methods can be developed for improving conditions on degraded to favor increased biological diversity and soil nutrition, also providing diverse types of textile natural fibers. This possibility would be turning agriculture from a threat to an opportunity for conservation. Considering presented issues, this paper is a point of start for further studies.

Besides the increasing knowledge on these complex cultivation systems and defining good farming practices and measure good farming practices, there is also necessity of designing addressed public policies and effective solutions, coordinating stakeholders interests.

Acknowledgements The authors gratefully acknowledge the Brazilian funding agency CAPES (Coordenacao de Aperfeicoamento de Pessoal de Nivel Superior) (Grant No. 001).

\section{Compliance with ethical standards}

Conflict of interest The authors declare that they have no conflict of interest.

\section{References}

1. Rieple A, Singh R (2010) A value chain analysis of the organic cotton industry: the case of UK retailers and Indian suppliers. Ecol Econ 69(11):2292-2302. https://doi.org/10.1016/j.ecole con.2010.06.025

2. Pal R (2014) Sustainable business development through designing approaches for fashion value chains. In: Muthu SS (ed) Roadmap to sustainable textiles and clothing. Springer, Singapore, pp 227-261. https://doi.org/10.1007/978-981-287-110-7

3. Pal R, Gander J (2018) Modelling environmental value: an examination of sustainable business models within the fashion industry. J Clean Prod 184:251-263. https://doi.org/10.1016/j. jclepro.2018.02.001

4. Nagendra $\mathrm{H}$ (2018) The global south is rich in sustainability lessons that students deserve to hear. Nature. https://www.natur e.com/articles/d41586-018-05210-0. Accessed on 12 Feb 2019. https://doi.org/10.1038/d41586-018-05210-0

5. Caniato F, Caridi M, Crippa L, Moretto A (2012) Environmental sustainability in fashion supply chains: an exploratory case based research. Int J Prod Econ 135:659-670. https://doi. org/10.1016/j.ijpe.2011.06.001

6. Romeiro AR (1998) Meio ambiente e dinâmica de inovações na agricultura. [Environment and dynamics of innovations in agriculture]. ISBN 85-7419-025-X. 1st ed. Sao Paulo/SP: FAPESP - Annablume Editora, v. 1.277p

7. Nair PR (1985) Classification of agroforestry systems. Agrofor Syst 3:97-128. https://doi.org/10.1023/A:1006278928088

8. Hong $Y$, Heerink $N$, Jin S, Berentsen $P$, Zhang L, van der Werf W (2017) Intercropping and agroforestry in China-current state and trends. Agr Ecosyst Environ 244:52-61. https://doi. org/10.1016/j.agee.2017.04.019

9. Yadav RP, Gupta B, Bhutia PL, Bisht JK, Pattanayak A (2019) Sustainable agroforestry systems and their structural components as livelihood options along elevation gradient in central Himalaya. Biol Agric Hortic 35(2):73-95. https://doi. org/10.1080/01448765.2018.1457982

10. Zhang D, Cheng S, Yang H, He L, Jiao W, Liu S, Min Q (2011) Ecological control effects on pest, pathogen and weed of multiple Species coexistence in paddy fields in traditional agricultural regions. Resour Sci 33(6):1032-1037. https://doi.org/10.3390/ su9020295

11. Valencia V, Wittman H, Blesh J (2019) Structuring markets for resilient farming systems. Agron Sustain Dev 39(2):25. https:// doi.org/10.1007/s13593-019-0572-4

12. Berthet ET, Segrestin B, Hickey GM (2016) Considering agro-ecosystems as ecological funds for collective design: new perspectives for environmental policy. Environ Sci Policy 61:108-115. https://doi.org/10.1016/j.envsci.2016.04.005

13. Fischer J, Brosi B, Daily GC, Ehrlich PR, Goldman R, Goldstein J, Lindenmayer DB, Manning AD, Mooney HA, Pejchar L (2008) Should agricultural policies encourage land sparing or wildlifefriendly farming? Front Ecol Environ 6:380-385. https://doi. org/10.1890/070019

14. Elevitch C, Mazaroli D, Ragone D (2018) Agroforestry standards for regenerative agriculture. Sustainability 10(9):3337. https:// doi.org/10.3390/su10093337

15. Dedeurwaerdere T, Hannachi M (2019) Socio-economic drivers of coexistence of landraces and modern crop varieties in agrobiodiversity rich Yunnan rice fields. Ecol Econ 159:177-188. https ://doi.org/10.1016/j.ecolecon.2019.01.026

16. United Nations (2019) About the sustainable development goals. https://www.un.org/sustainabledevelopment/sustainabl e-development-goals/. Accessed on 09 May 2019

17. Mair S, Druckman A, Jackson T (2019) Higher wages for sustainable development? Employment and carbon effects of paying a living wage in global apparel supply chains. Ecol Econ 159:1123. https://doi.org/10.1016/j.ecolecon.2019.01.007

18. Prost L, Berthet ET, Cerf M, Jeuffroy MH, Labatut J, Meynard JM (2017) Innovative design for agriculture in the move towards sustainability: scientific challenges. Res Eng Des 28:119-129. https://doi.org/10.1007/s00163-016-0233-4

19. Pigford AAE, Hickey GM, Klerkx L (2018) Beyond agricultural innovation systems? Exploring an agricultural innovation ecosystems approach for niche design and development in sustainability transitions. Agric Syst 164:116-121. https://doi. org/10.1016/j.agsy.2018.04.007

20. Textile Exchange (2019) Who we are. https://textileexchange .org/about-us/. Accessed on 5 Jan 2019

21. Macchion L, Moretto A, Caniato F, Caridi M, Danese P, Vinelli A (2015) Production and supply network strategies within the fashion industry. Int J Prod Econ 163:173-188. https://doi. org/10.1016/j.ijpe.2014.09.006

22. Franca $C L$, Broman $G$, Robèrt $K H$, Basile $G$, Trygg $L$ (2017) An approach to business model innovation and design for strategic sustainable development. J Clean Prod 140:155-166. https://doi. org/10.1016/j.jclepro.2016.06.124

23. Geissdoerfer M, Savaget P, Bocken NM, Hultink EJ (2017) The circular economy - a new sustainability paradigm? J Clean Prod 143:757-768. https://doi.org/10.1016/j.jclepro.2016.12.048

24. Amit R, Han X (2017) Value creation through novel resource configurations in a digitally enabled world. Strateg Entrep J 11(3):228-242. https://doi.org/10.1002/sej.1256

25. Kantola J, Liu Y, Peura P, De Leeuw T, Zhang Y, Naaranoja M, Huisingh D (2017) Innovative products and services for sustainable societal development: current reality, future potential and challenges. J Clean Prod 162:S1-S10. https://doi.org/10.1016/j.jclep ro.2017.07.091

26. Broman Gl, Robèrt KH (2017) A framework for strategic sustainable development. J Clean Prod 140:17-31. https://doi. org/10.1016/j.jclepro.2016.02.055 
27. Hurmekoski E, Jonsson R, Korhonen J, Jänis J, Mäkinen M, Leskinen $P$, Hetemäki L (2018) Diversification of the forest industries: role of new wood-based products. Can J For Res 48(12):14171432. https://doi.org/10.1139/cjfr-2018-0116

28. Khandegar V, Saroha AK (2013) Electrocoagulation for the treatment of textile industry effluent-a review. J Environ Manag 128:949-963. https://doi.org/10.1016/j.jenvman.2013.06.043

29. Nguyen NH, Beeton RJ, Halog A (2014) Who influence the environmental adaptation process of small and medium sized textile and garment companies in Vietnam? In: Muthu SS (ed) Roadmap to sustainable textiles and clothing. Springer, Singapore, pp 189-207. https://doi.org/10.1007/978-981-287-110-7_7

30. Magnuson B, Reimres V, Chao F (2017) Re-visiting an old topic with a new approach: the case of ethical clothing. J Fash Mark Manag Int J 21(3):400-418. https://doi.org/10.1108/ JFMM-10-2016-0091

31. Khurana K, Ricchetti M (2016) Two decades of sustainable supply chain management in the fashion business, an appraisal. J Fash Mark Manag 20(1):89-104. https://doi.org/10.1108/ JFMM-05-2015-0040

32. Maccarthy Bart L, Jayarathne PGSA (2012) Sustainable collaborative supply networks in the international clothing industry: a comparative analysis of two retailers. Prod Plan Control 23(4):252-268. https://doi.org/10.1080/09537287.2011.627655

33. Bocken NMP, Short W (2016) Towards a sufficiency-driven business model: experiences and opportunities. Environ Innov Soc Transit 18:41-61. https://doi.org/10.1016/j.eist.2015.07.010

34. Fletcher K (2010) Slow fashion: an invitation for systems change. Fashion Pract 2(2):259-265. https://doi.org/10.2752/17569 $3810 \times 12774625387594$

35. Fletcher K, Grose L (2012) Fashion and sustainability: design for change. Laurence King, London

36. Cattani IM, Baruque-Ramos J (2014) Fibra de buriti (Mauritia flexuosa Mart.) e aplicações em produtos têxteis. $2^{\circ}$ CONTEXMOD 1(2):15

37. Pezzolo DB (2012) Tecidos: História, Tramas, Tipos e Usos, 3a edn. SENAC, São Paulo

38. Sanjay MR, Madhu P, Jawaid M, Senthamaraikannan P, Senthil S, Pradeep S (2018) Characterization and properties of natural fiber polymer composites: a comprehensive review. J Clean Prod 172:566-581. https://doi.org/10.1016/j.jclepro.2017.10.101

39. Elseify LA, Midani M, Shihata LA, El-Mously H (2019) Review on cellulosic fibers extracted from date palms (Phoenix dactylifera L.) and their applications. Cellulose. https://doi.org/10.1007/ s10570-019-02259-6

40. Sfiligoj Smole M, Hribernik S, Stana Kleinschek K, Kreze T (2013) Plant fibres for textile and technical applications. In: Grundas S, Stepniewski A (eds) Advances in agrophysical research. IntechOpen, pp 369-398. https://doi.org/10.5772/52372

41. Benini KCCC (2011) Development and characterization of polymeric composites reinforced with lignocellulosic fibers: HIPS/ fibers of the green coconut shell and sugarcane bagasse. $125 \mathrm{f}$. Master's Dissertation in Mechanical Engineering

42. DeLonge MS, Miles A, Carlisle L (2016) Investing in the transition to sustainable agriculture. Environ Sci Policy 55:266-273. https ://doi.org/10.1016/j.envsci.2015.09.013

43. lacob SE (2015) The role of the forest resources in the socioeconomic development of the rural areas. Procedia Econ Finance 23:1578-1583. https://doi.org/10.1016/S2212-5671(15)00415-3

44. Costa MP, Schoeneboom JC, Oliveira SA, Viñas RS, De Medeiros GA (2018) A socio-eco-efficiency analysis of integrated and non-integrated crop-livestock-forestry systems in the Brazilian Cerrado based on LCA. J Clean Prod 171:1460-1471. https://doi. org/10.1016/j.jclepro.2017.10.063

45. Berthet ET, Hickey GM, Klerkx L (2018) Opening design and innovation processes in agriculture: insights from design and management sciences and future directions. Agric Syst 165:111-115. https://doi.org/10.1016/j.agsy.2018.06.004

46. Zulfiqar F, Thapa GB (2016) Is 'Better cotton' better than conventional cotton in terms of input use efficiency and financial performance? Land Use Policy 52:136-143. https://doi. org/10.1016/j.landusepol.2015.12.013

47. Zulfiqar F, Datta A, Thapa GB (2017) Determinants and resource use efficiency of "better cotton": an innovative cleaner production alternative. J Clean Prod 166:1372-1380. https://doi.org/10.1016/j.jclepro.2017.08.155

48. Chaudhry RM, Wakelyn PJ (2006) Organic cotton production. Woodhead Publishing, Cambridge (forthcoming)

49. De Oliveira CSC, Oliveira-Filho EC (2014) Agricultura ecológica e indústria têxtil: o papel da comunicação para o algodão orgânico no Brasil. Universitas: Arquitetura e Comunicação Social. https://doi.org/10.5102/uc.v11i1.2429

50. Yang PPJ, Lay OB (2004) Applying ecosystem concepts to the planning of industrial areas: a case study of Singapore's Jurong Island. J Clean Prod 12(8-10):1011-1023. https://doi. org/10.1016/j.jclepro.2004.02.028

51. Glin LC, Mol AP, Oosterveer P, Vodouhe SD (2012) Governing the transnational organic cotton network from Benin. Glob Netw 12(3):333-354. https://doi.org/10.111 $1 / \mathrm{j} .1471-0374.2011 .00340 . x$

52. Bachmann F (2012) Potential and limitations of organic and fair trade cotton for improving livelihoods of smallholders: evidence from Central Asia. Renew Agric Food Syst 27(2):138147. https://doi.org/10.1017/S1742170511000202

53. Krishnamurthy L, Krishnamurthy PK, Rajagopal I, Solares AP (2017) Can agroforestry systems thrive in the drylands? Characteristics of successful agroforestry systems in the arid and semi-arid regions of Latin America. Agrofor Syst. https://doi. org/10.1007/s10457-017-0143-0

54. LaCanne CE, Lundgren JG (2018) Regenerative agriculture: merging farming and natural resource conservation profitably. PeerJ 6:e4428. https://doi.org/10.7717/peerj.4428

55. Dixon RK, Winjum JK, Andrasko KJ, Lee JJ, Schroeder PE (1994) Integrated land-use systems: assessment of promising agroforest and alternative land-use practices to enhance carbon conservation and sequestration. Clim Change 27(1):71-92. https://doi.org/10.1007/BF01098474

56. Jose S (2009) Agroforestry for ecosystem services and environmental benefits: an overview. Agrofor Syst 76:1-10. https ://doi.org/10.1007/s10457-009-9229-7

57. Smith J, Pearce BD, Wolfe MS (2013) Reconciling productivity with protection of the environment: is temperate agroforestry the answer? Renew Agric Food Syst 28(1):80-92

58. Quandt A, Neufeldt H, McCabe JT (2018) Building livelihood resilience: what role does agroforestry play? Clim Dev. https ://doi.org/10.1080/17565529.2018.1447903

59. Rumpel C, Amiraslani F, Koutika L S, Smith P, Whitehead D, Wollenberg, E (2018) Put more carbon in soils to meet Paris climate pledges. Nature. https://www.nature.com/articles/ d41586-018-07587-4. Accessed: 12 Feb 2019. https://doi. org/10.1038/d41586-018-07587-4

60. Rhodes CJ (2017) The imperative for regenerative agriculture. Sci Prog 100(1):80-129

61. Touzard JM, Temple L, Faure G, Triomphe B (2015) Innovation systems and knowledge communities in the agriculture and agrifood sector: a literature review. J Innov Econ Manag. https ://doi.org/10.3917/jie.017.0117

62. Watts N (2015) Agricultural systems and socio-natures: towards an actor-network theory informed political ecology of agriculture. Geogr Compass 9:225-236. https://doi. org/10.1111/gec3.12212 
63. Textile Exchange (2018) Regenerative agriculture in the textile supply chain. Textile Exchange, Wrangler, The North Face \& Pure Strategies

64. Rana S, Pichandi S, Parveen S, Fangueiro R (2014) Natural plant fibers: production, processing, properties and their sustainability parameters. In: Muthu SS (ed) Roadmap to sustainable textiles and clothing. Springer, Singapore, pp 1-35. https://doi. org/10.1007/978-981-287-065-0_1

65. Cardoso, N (2017) Agroecological cotton in the Brazilian semiarid: from production to commercialization. Dissertation Masters Agroecology

66. Ferraz FPC (2018) Sustainability in the cotton supply chain: a case study of the relationship between a sports footwear company and organic cotton producers. Master's Thesis Management for Competitiveness

67. Lima PJ (2005) Agroecological cotton: an experiment in the semi-arid region of Ceará. Agric Exp Agroecol 2(3):9-22

68. Zhang D, Du G, Sun Z, Bai W, Wang Q, Feng L, Zheng J, Zhang Z, Liu Y, Yang S, Yang N (2018) Agroforestry enables high efficiency of light capture, photosynthesis and dry matter production in a semi-arid climate. Eur J Agron 94:1-11. https://doi.org/10.1016/j. eja.2018.01.001

69. Araujo ACD, Beltrao NEDM, Morais MDS, Araujo JDLO, Cunha JLXL, Paixao SL (2008) Agroeconomic indicators on the evaluation of cotton + peanut intercropping. Cienc Agrotecnol 32(5):1467-1472. https://doi.org/10.1590/S1413-7054200800 0500017

70. Wang Q, Han S, Zhang L, Zhang D, van der Werf W, Evers JB, Sun H, Su Z, Zhang S (2016) Density responses and spatial distribution of cotton yield and yield components in jujube (Zizyphus jujube)/cotton (Gossypium hirsutum) agroforestry. Eur J Agron 79:58-65. https://doi.org/10.1016/j.eja.2016.05.009

71. Zhang D, Zhang L, Liu J, Han S, Wang Q, Evers J, Liu J, Van der Werf W, Li L (2014) Plant density affects light interception and yield in cotton grown as companion crop in young jujube plantations. Field Crops Res 169:132-139. https://doi.org/10.1016/j. fcr.2014.09.001

72. Wang Q, Zhang D, Zhang L, Han S, van der Werf W, Evers JB, Su $Z$, Anten NP (2017) Spatial configuration drives complementary capture of light of the understory cotton in young jujube plantations. Field crops Res 213:21-28. https://doi.org/10.1016/j. fcr.2017.07.016

73. Gnangle CP, Gbemavo C, Aihou K (2013) Productivity of cotton and sorghum in an agroforestry system of shea trees (Vitellaria paradoxa Gaertn) in northern Benin. Nat Sci 5(2):207-213. https ://doi.org/10.4236/ns.2013.52031

74. Wanvestraut RH, Jose S, Nair PR, Brecke BJ (2004) Competition for water in a pecan (Carya illinoensis K. Koch)-cotton (Gossypium hirsutum L.) alley cropping system in the southern United States. Agrofor Syst 60(2):167-179. https://doi.org/10.1023/ B:AGFO.0000013292.29487.7a

75. Sandin G, Peters GM, Svanstrom M (2013) Moving down the cause-effect chain of water and land use impacts: an LCA case study of textile fibres. Resour Conserv Recycl 73:104-113. https ://doi.org/10.1016/j.resconrec.2013.01.020

76. Puri S, Bangarwa KS, Singh S (1995) Influence of multipurpose trees on agricultural crops in arid regions of Haryana, India. J Arid Environ 30(4):441-451. https://doi.org/10.1006/ jare.1995.0038

Publisher's Note Springer Nature remains neutral with regard to jurisdictional claims in published maps and institutional affiliations. 